\title{
Prevalence of self-injury, suicidal ideation, plans and attempts in adolescents aged 13 to 19 years of age
}

\begin{abstract}
Introduction. Increased suicide rates, both among adults and adolescents, have been seen in Poland over recent years.

Aim. The aim of the study was to determine the prevalence of self-injury, suicide ideation, plans and attempts in adolescents aged 13 to 19 years.

Material and methods. The study encompassed the total number of 6883 individuals aged 13 to 19 years, $69 \%$ of them being girls and 31\% - boys. All respondents lived in Lubelskie Province. The research was conducted using a questionnaire designed by the authors.

Results. In the group composed of 6883 adolescents living in Lublin Province, suicide ideation was reported by $47.65 \%$ of the respondents, suicide plans by $32.35 \%$, suicide attempts were carried out by $10 \%$ of adolescents and self-injury by $24.91 \%$ of the respondents aged 13 to 19 years.

Conclusions. The greatest prevalence of suicide ideation, plans and attempts, as well as self-injuries, were recorded in the group of adolescents aged 17. The adolescents living in the urban areas are more likely to inflict self-injury than those living in rural areas. Furthermore, adolescents with suicidal tendencies, e.g. attempting suicide and self-injury, are more prone to alcohol and substance abuse. It needs emphasizing that many adolescents with suicidal tendencies, compared against those who did not carry them out, have past experience of psychological, physical and sexual violence in the family, have been raised by a single parent or in families, where one of the parents abused alcohol.
\end{abstract}

Keywords: suicide, self-injury, adolescents.

DOI: $10.1515 /$ pjph-2015-0025

\section{INTRODUCTION}

Increased suicide rates, both among adults and adolescents, have been seen in Poland over recent years. Hołyst [1] points out that suicide is one of the top five causes of death for adolescents aged 15 to 19 years worldwide. Napieralska [2] shows that the suicide rate is on the rise among children and adolescents of both sexes, aged 10 to 19 .

According to Gmitrowicz [3], the studies of suicide ideation, plans and attempts in adolescents should be updated on a continuous basis due to a significant variability of epidemiological data resulting from cultural and social-economic transformations as well as due to including by researchers various factors modifying the suicide risk. According to the statistics of the General Police Headquarters in 2013 in Poland there were 418 suicide attempts among adolescents aged 14-19 years and in 2012 the total of 343 individuals attempted suicide, out of which 165 attempts were fatal [4]. Rosa and Gmitrowicz [5-7], on the basis of research carried out in 2004 involving adolescents aged 15-19 years living in Łódź region indicate that suicidal ideation occurs in $14.1 \%$ of respondents, whereas $3.8 \%$ of them attempted to commit suicide. These authors [4] point out that the suicide rate in 2006 for individuals aged 15-19 was 9.4 per 100 thousand. The data presented by the General Office of Statistics (GUS) [8] indicate that 302 suicide deaths were reported in 2008 among adolescents aged 10-19 years. For the adolescents aged between 15 and 19, suicide death rate was 16.2 for boys and 4.1 for girls. The highest suicide death rate was reported in Podlaskie Province (13.3), Lubelskie Province (12.9) and Zachodniopomorskie Province (11.6) [8].

It is hard to estimate the prevalence of self-injury in adolescents from the non-clinical sample, i.e. those not undergoing psychiatric treatment, as there are no precise statistics available. Żechowski and Namysłowska [9] point out that the number of individuals inducing self-injuries on themselves has risen, both in the general and clinical population.

According to Klonsky [10], numerous behaviors like suicidal ideation, as well as alcohol consumption and taking illegal drugs, rarely coexist with self-injury. The results obtained by Pawłowska et al. [11] demonstrate that a huge number of adolescents inducing self-injury on themselves,

\footnotetext{
${ }^{1}$ 2nd Department of Psychiatry and Psychiatric Rehabilitation, Medical University of Lublin, Poland

${ }^{2}$ Department of Psychiatric Nursing, Medical University of Lublin, Poland

${ }^{3}$ Prof. M. Kaczyński Neuropsychiatric Hospital Independent Public Health Care Facility in Lublin, Poland
} 
also report other risky behaviors, like suicidal ideation and plans or even attempts to kill themselves, alcohol and substance abuse, playing truant and running away from home.

\section{AIM}

The aim of the study was to determine the prevalence of self-injury, suicidal ideation and plans as well as suicide attempts among adolescents aged 13-19 years.

\section{MATERIAL AND METHODS}

The research encompassed the total number of 6883 individuals aged 13-19 years, out of whom 69\% were girls and $31 \%$ - boys. All respondents lived in Lubelskie Province, $45.46 \%$ in the urban areas and $54.54 \%$ in the rural areas.

The research was approved by the Bioethics Committee of the Medical University of Lublin, by the School Authorities, moreover, the parents' permission was obtained as well as of school principals and of students. The research was conducted

TABLE 1. Comparison of the number of girls and boys reporting suicidal ideation, plans as well as attempting suicide and performing self-injury.

\begin{tabular}{lccccc}
\hline \hline \multirow{2}{*}{$\begin{array}{c}\text { Self-destructive } \\
\text { behaviours }\end{array}$} & \multicolumn{2}{c}{ Girls } & \multicolumn{2}{c}{ Boys } & \multirow{2}{*}{$\chi^{2}$} \\
\cline { 2 - 5 } & $\mathrm{N}$ & $\%$ & $\mathrm{~N}$ & $\%$ & \\
\hline Suicidal ideation & 1255 & 28.87 & 365 & 18.78 & $71.59^{* * *}$ \\
\hline Suicide intent & 765 & 19.73 & 214 & 12.62 & $41.18^{* * *}$ \\
\hline Suicide attempts & 260 & 5.97 & 78 & 4.03 & $9.93 * *$ \\
\hline Self-injury & 704 & 16.24 & 168 & 8.67 & $64.09 * * *$ \\
\hline
\end{tabular}

$* \mathrm{p}<0.05 ; * * \mathrm{p}<0.01 ; * * * \mathrm{p}<0.001$ in all schools where the principals' consent was obtained and attempts were made to encompass by survey the largest possible group of students.

In the study a questionnaire designed by the authors was used, based on which the following data were determined: gender, age, place of residence, level of education, family structure of respondents (being raised in a two-parent (complete) family, reconstituted family, single parent family by single fathers of single mothers), using psychoactive agents by adolescents, alcohol abuse by a family member, experience of emotional, physical and sexual violence from family members, performing self-harm by the respondents, reporting suicidal ideation, plans and making suicide attempts.

\section{RESULTS}

The first stage of the analyses involved a comparison using a chi-square test, comparing the number of girls and boys who reported suicidal ideation, intents and performed self-injury or attempted suicide (Table 1).

In the entire group of teenage respondents, the suicidal ideation is reported by $47.65 \%$ of individuals, suicide plans by $32.35 \%$, the total of $10 \%$ of the adolescents admit to suicide attempts and $24.91 \%$ of the respondents admit to self-injury. Girls are more likely than boys report suicidal ideation and plans or perform self-injury and attempt suicide. The tables below (Table 2 and 3) provide information on the age of adolescents reporting self-destructive behaviors analysed in the study.

It needs emphasizing that 17 -year-olds are most likely to experience suicide-related behaviors, like suicidal ideation, plans, as well as performing suicide attempts or self-injury The self-destructive behaviors described above are demonstrated by a few percent of adolescents aged 13-15, whilst

TABLE 2. Age of adolescents reporting suicidal ideation and plans.

\begin{tabular}{|c|c|c|c|c|c|c|c|c|c|c|c|c|}
\hline \multirow{3}{*}{ Age } & \multicolumn{6}{|c|}{ Suicidal ideation } & \multicolumn{6}{|c|}{ Suicide plans } \\
\hline & \multicolumn{2}{|c|}{ Entire group } & \multicolumn{2}{|c|}{ Girls } & \multicolumn{2}{|c|}{ Boys } & \multicolumn{2}{|c|}{ Entire group } & \multicolumn{2}{|c|}{ Girls } & \multicolumn{2}{|c|}{ Boys } \\
\hline & $\mathrm{N}$ & $\%$ & $\mathrm{~N}$ & $\%$ & $\mathrm{~N}$ & $\%$ & $\mathrm{~N}$ & $\%$ & $\mathrm{~N}$ & $\%$ & $\mathrm{~N}$ & $\%$ \\
\hline 13 & 13 & 0.75 & 10 & 0.8 & 3 & 0.82 & 6 & 0.57 & 4 & 0.52 & 2 & 0.94 \\
\hline 14 & 99 & 5.69 & 69 & 5.52 & 20 & 5.49 & 59 & 5.57 & 40 & 5.25 & 13 & 6.10 \\
\hline 15 & 84 & 4.82 & 64 & 5.12 & 16 & 4.40 & 52 & 4.91 & 36 & 4.72 & 13 & 6.10 \\
\hline 16 & 249 & 14.30 & 161 & 12.88 & 64 & 17.58 & 158 & 14.91 & 103 & 13.52 & 37 & 17.37 \\
\hline 17 & 758 & 43.54 & 561 & 44.88 & 142 & 39.01 & 450 & 42.45 & 336 & 44.09 & 75 & 35.21 \\
\hline 18 & 469 & 26.94 & 342 & 27.36 & 95 & 26.10 & 293 & 27.64 & 217 & 28.48 & 58 & 27.23 \\
\hline 19 & 69 & 3.96 & 43 & 3.44 & 24 & 6.60 & 42 & 3.96 & 26 & 3.41 & 15 & 7.04 \\
\hline
\end{tabular}

TABLE 3. Age of adolescents performing suicide attempts and self-injury.

\begin{tabular}{|c|c|c|c|c|c|c|c|c|c|c|c|c|}
\hline \multirow{3}{*}{ Age } & \multicolumn{6}{|c|}{ Suicide attempts } & \multicolumn{6}{|c|}{ Self-injury } \\
\hline & \multicolumn{2}{|c|}{ Entire group } & \multicolumn{2}{|c|}{ Girls } & \multicolumn{2}{|c|}{ Boys } & \multicolumn{2}{|c|}{ Entire group } & \multicolumn{2}{|c|}{ Girls } & \multicolumn{2}{|c|}{ Boys } \\
\hline & $\mathrm{N}$ & $\%$ & $\mathrm{~N}$ & $\%$ & $\mathrm{~N}$ & $\%$ & $\mathrm{~N}$ & $\%$ & $\mathrm{~N}$ & $\%$ & $\mathrm{~N}$ & $\%$ \\
\hline 13 & 1 & 0.27 & 1 & 0.39 & 0 & 0.00 & 2 & 0.22 & 0 & 0.00 & 2 & 1.20 \\
\hline 14 & 24 & 6.59 & 16 & 6.20 & 5 & 6.49 & 60 & 6.45 & 41 & 5.86 & 14 & 8.38 \\
\hline 15 & 16 & 4.40 & 13 & 5.04 & 3 & 3.90 & 60 & 6.45 & 44 & 6.29 & 13 & 7.78 \\
\hline 16 & 58 & 15.93 & 42 & 16.28 & 9 & 11.69 & 140 & 15.05 & 100 & 14.29 & 29 & 17.37 \\
\hline 17 & 150 & 41.21 & 103 & 39.92 & 33 & 42.86 & 408 & 43.87 & 320 & 45.71 & 62 & 37.13 \\
\hline 18 & 104 & 28.57 & 77 & 29.84 & 23 & 29.87 & 234 & 25.16 & 176 & 25.14 & 40 & 23.95 \\
\hline 19 & 11 & 3.02 & 6 & 2.33 & 4 & 5.2 & 26 & 2.80 & 19 & 2.71 & 7 & 4.19 \\
\hline
\end{tabular}


the ratio increases to $10 \%$ in sixteen-year-olds. There is a huge increase in seventeen-year-olds, as over $40 \%$ of them engage in some suicide-related behaviors. The ratio decreases in case of 18-year-olds (to 20-30\%) to decrease even more a year later - only a small percentage of 19 -year-olds is affected. The results show that girls aged 15 to 16 report more frequent suicide attempts than boys. Conversely, boys aged 7 to 19 are more likely to attempt suicide than girls that age. This means that about $29 \%$ of 18 -year-olds of both sexes attempt suicide. Girls aged 17 and 18 are more likely to report self-injury than boys the same age. Yet, boys aged 13 to 16 , as well as those aged 19 are more likely than girls to induce self-injury on themselves.

Table 4 provides data on the place of residence of the respondents.

TABLE 4. Comparison of the place of residence of adolescents reporting suicidal ideation, plans as well as attempting suicide and performing self-injury.

\begin{tabular}{|c|c|c|c|c|c|c|}
\hline \multirow{2}{*}{\multicolumn{2}{|c|}{$\begin{array}{c}\text { Self-destructive behaviours } \\
\mathrm{N}\end{array}$}} & \multicolumn{2}{|c|}{ Urban areas } & \multicolumn{2}{|c|}{ Rural areas } & \multirow{2}{*}{$\chi^{2}$} \\
\hline & & $\%$ & $\mathrm{~N}$ & $\%$ & & \\
\hline \multirow{4}{*}{$\begin{array}{l}\text { Entire } \\
\text { group }\end{array}$} & Suicidal ideation & 800 & 26.53 & 891 & 25.13 & 1.99 \\
\hline & Suicide plans & 470 & 17.22 & 555 & 17.77 & 0.52 \\
\hline & Suicide attempts & 172 & 5.70 & 184 & 5.20 & 0.85 \\
\hline & Self-injury & 475 & 15.81 & 432 & 12.23 & $17.57 * * *$ \\
\hline \multirow{4}{*}{ Girls } & Suicidal ideation & 567 & 29.69 & 657 & 28.06 & 1.35 \\
\hline & Suicide plans & 330 & 19.26 & 413 & 19.90 & 0.24 \\
\hline & Suicide attempts & 120 & 6.27 & 135 & 5.76 & 0.49 \\
\hline & Self-injury & 354 & 18.56 & 334 & 14.31 & $13.97 * * *$ \\
\hline \multirow{4}{*}{ Boys } & Suicidal ideation & 170 & 19.25 & 186 & 18.56 & 0.38 \\
\hline & Suicide plans & 99 & 12.45 & 107 & 12.63 & 0.16 \\
\hline & Suicide attempts & 36 & 4.08 & 40 & 4.02 & 0.05 \\
\hline & Self-injury & 84 & 9.56 & 79 & 7.91 & 1.70 \\
\hline
\end{tabular}

${ }^{*} \mathrm{p}<0.05 ; * * \mathrm{p}<0.01 ; * * * \mathrm{p}<0.001$

TABLE 5. Use of psychoactive substances by adolescents reporting suicidal ideation and plans.

\begin{tabular}{|c|c|c|c|c|c|c|}
\hline \multirow{3}{*}{ Variables } & \multicolumn{3}{|c|}{ Suicidal ideation } & \multicolumn{3}{|c|}{ Suicide plans } \\
\hline & YES & NO & \multirow{2}{*}{$\chi^{2}$} & $\mathrm{NO}$ & YES & \multirow{2}{*}{$\chi^{2}$} \\
\hline & $\%$ & $\%$ & & $\%$ & $\%$ & \\
\hline $\begin{array}{l}\text { Binge } \\
\text { drinking }\end{array}$ & 40.27 & 57.35 & $141.45^{* * *}$ & 40.69 & 59.96 & $121.20 * * *$ \\
\hline $\begin{array}{l}\text { Illegal } \\
\text { drugs }\end{array}$ & 19.22 & 33.72 & $125.15^{* * *}$ & 18.08 & 36.95 & $150.56^{* * *}$ \\
\hline
\end{tabular}

${ }^{*} \mathrm{p}<0.05 ; * * \mathrm{p}<0.01 ; * * * \mathrm{p}<0.001$

TABLE 6. Use of psychoactive agents by adolescents who perform suicide attempts and self-injuries.

\begin{tabular}{|c|c|c|c|c|c|c|}
\hline \multirow{3}{*}{ Variables } & \multicolumn{3}{|c|}{ Suicide attempts } & \multicolumn{3}{|c|}{ Self-injuries } \\
\hline & NO & YES & \multirow{2}{*}{$\chi^{2}$} & $\mathrm{NO}$ & YES & \multirow{2}{*}{$\chi^{2}$} \\
\hline & $\%$ & $\%$ & & $\%$ & $\%$ & \\
\hline $\begin{array}{l}\text { Binge } \\
\text { drinking }\end{array}$ & 43.20 & 66.09 & $69.79 * * *$ & 41.21 & 66.71 & $190.83 * * *$ \\
\hline $\begin{array}{l}\text { Illegal } \\
\text { drugs }\end{array}$ & 21.50 & 49.38 & $131.27 * * *$ & 19.88 & 41.87 & $182.97 * * *$ \\
\hline
\end{tabular}

${ }^{*} \mathrm{p}<0.05 ; * * \mathrm{p}<0.01 ; * * * \mathrm{p}<0.001$
Adolescents living in the urban areas are more likely to inflict self-injury than those living in rural areas. However, the prevalence of suicidal ideation, plans and attempts is equal for both the adolescents living in the urban and rural areas.

The data regarding the number of adolescents informing and non-informing about suicidal ideation, plans, attempts and self-injury who use psychoactive substances and abuse alcohol is presented in the tables below (Tables 5 and 6).

Significantly more adolescents informing about suicidal ideation and plans and performing suicide attempts and selfinjury get drunk and use illegal drugs. In the tables below (Table 7 and 8) a comparison of the number of adolescents exhibiting self-destructive behaviours who experienced various forms of violence is included.

Significantly more adolescents reporting suicidal ideation and plans, as well as performing suicide attempts and selfinjury, have an experience of psychological, physical and sexual violence in the family.

Afterwards, an analysis was made of the data concerning the family structure (Tables 9 and 10) and alcohol abuse among them (Tables 11 and 12), obtained for adolescents exhibiting and non exhibiting self-destructive behaviours.

TABLE 7. Experience of violence by the adolescents reporting suicidal ideation and plans.

\begin{tabular}{|c|c|c|c|c|c|c|c|c|}
\hline \multirow{3}{*}{ Violence } & \multicolumn{4}{|c|}{ Suicidal ideation } & \multicolumn{4}{|c|}{ Suicide plans } \\
\hline & NO & YES & \multirow[b]{2}{*}{$\lambda^{2}$} & & NO & YES & \multirow{2}{*}{$x^{2}$} & \multirow[b]{2}{*}{1} \\
\hline & $\%$ & $\%$ & & & $\%$ & $\%$ & & \\
\hline $\begin{array}{l}\text { Violence } \\
\text { in total }\end{array}$ & 38.88 & 70.40 & 238.22 & 0.001 & 42.22 & 74.74 & 194.44 & 0.001 \\
\hline Psychological & 19.89 & 47.27 & 216.05 & 0.001 & 23.13 & 50.34 & 163.41 & 0.001 \\
\hline Physical & 13.82 & 30.03 & 100.41 & 0.001 & 14.83 & 34.72 & 115.95 & 0.001 \\
\hline Sexual & 0.99 & 3.61 & 22.49 & 0.001 & 0.99 & 4.98 & 40.02 & 0.001 \\
\hline
\end{tabular}

TABLE 8. Experience of violence by adolescents performing suicide attempts and self-injury.

\begin{tabular}{lcccccccccc}
\hline \hline \multirow{3}{*}{ Violence } & \multicolumn{3}{c}{ Suicide attempts } & \multicolumn{5}{c}{ Self-injury } \\
\cline { 2 - 7 } & NO & YES & & & & NO & YES & \multirow{2}{*}{$\chi^{2}$} & $\mathrm{p}$ & $\mathrm{p}$ \\
\cline { 2 - 6 } & $\%$ & $\%$ & & & $\%$ & $\%$ & & \\
\hline $\begin{array}{l}\text { Violence } \\
\text { in total }\end{array}$ & 46.79 & 84.57 & 93.49 & 0.001 & 44.04 & 73.13 & 133.62 & 0.001 \\
\hline Psychological & 26.73 & 60.69 & 90.80 & 0.001 & 24.48 & 48.74 & 112.29 & 0.001 \\
\hline Physical & 17.40 & 43.35 & 70.62 & 0.001 & 16.48 & 31.72 & 58.52 & 0.001 \\
\hline Sexual & 1.34 & 9.20 & 55.24 & 0.001 & 1.27 & 4.59 & 23.86 & 0.001 \\
\hline
\end{tabular}

TABLE 9. Family status in adolescents reporting and non-reporting suicidal ideation and plans.

\begin{tabular}{|c|c|c|c|c|c|c|}
\hline \multirow{3}{*}{ Family } & \multicolumn{3}{|c|}{ Suicidal ideation } & \multicolumn{3}{|c|}{ Suicide plans } \\
\hline & NO & YES & \multirow{2}{*}{$\chi^{2}$} & NO & YES & \multirow{2}{*}{$\chi^{2}$} \\
\hline & $\%$ & $\%$ & & $\%$ & $\%$ & \\
\hline $\begin{array}{l}\text { Two-parent } \\
\text { (complete) }\end{array}$ & 88.33 & 80.40 & \multirow{3}{*}{$60.85 * * *$} & 87.85 & 77.92 & \multirow{3}{*}{$67.86^{* * *}$} \\
\hline Single-parent & 11.24 & 18.73 & & 11.70 & 21.03 & \\
\hline Reconstituted & 0.43 & 0.87 & & 0.44 & 1.05 & \\
\hline
\end{tabular}

$* \mathrm{p}<0.05 ; * * \mathrm{p}<0.01 ; * * * \mathrm{p}<0.001$ 
The results obtained indicate that significantly more adolescents reporting suicidal ideation and performing suicide attempts and self-injury, as compared to those non exhibiting self destructing behaviours, are raised in single-parent families or reconstituted families and significantly less in a two-parent (complete) family.

In Tables 11 and 12 a comparison was made of adolescents exhibiting and non exhibiting self-destructive behaviours whose parents abuse alcohol.

Significantly more adolescents reporting suicidal ideation and plans as well as performing self-injury and attempting suicide report alcohol abuse by a family member.

\section{DISCUSSION}

The results obtained on the basis of statistical analyses indicate that in the entire group of examined adolescents the suicidal ideation was reported by $47.65 \%$ of the individuals, suicide plans by $32.35 \%$, the total of $10 \%$ of adolescents admit to suicide attempts and $24.91 \%$ of respondents admit to performing self-injuries. It should be pointed out that the greatest prevalence of suicidal ideation, plans, attempts and self-injury occurs in 17-year-olds. Significantly more girls, as compared to boys, perform suicide attempts and selfinjury and report suicidal ideation and plans. Similar results were obtained by Zoroglu et al. [12], who found that $13.2 \%$ of girls and $5.4 \%$ of boys attempt suicide. Lewinsohn et al. [13] claim that in a group of adolescents aged 12-18 suicide is attempted by significantly more girls than boys. Lewinsohn et al. [13] point out that in the group of girls above 13 years of age there is an increase in suicide attempts reaching its maximum value between 15 and 18 years of age and then it decreases. In the opinion of these researchers [13] the largest number of boys attempting suicide are at the age of 15 .

The findings of this research suggests that one's place of residence (be it rural or urban areas) does not affect the prevalence of suicidal ideation, plans and attempts among adolescents. At the same time, adolescents living in urban areas are more likely to inflict self-injury than their peers from rural areas. These results are similar to the findings of Borges et al. [14]. This study suggests that the place of residence does not have any impact on the likelihood of suicide attempts. There is a lack of data regarding the prevalence of self-injuries performed by adolescents living in the urban and rural areas.

The results of the study show that the adolescents reporting suicidal ideation and plans, as well as attempting suicide and inflicting self-injury, are more prone to alcohol and substance abuse. Such thesis can be confirmed by a few researchers [15-19]. They point out to a number of factors affecting suicide attempts in adolescents, including alcohol abuse and using illegal drugs. According to $\mathrm{Wu}$ et al. [19] and Nock et al. [15] the adolescents admitting to suicidal ideation are much more likely to abuse alcohol and use psychoactive agents, as compared to the control group.

The results obtained in this study highlight the family factors which may be of crucial importance in the development of the discussed self-destructive behaviours in adolescents. Significantly more adolescents reporting suicidal ideation
TABLE 10. Family status in adolescents performing suicide attempts and self-injuries.

\begin{tabular}{|c|c|c|c|c|c|c|}
\hline \multirow{3}{*}{ Family } & \multicolumn{3}{|c|}{ Suicide attempts } & \multicolumn{3}{|c|}{ Self-injuries } \\
\hline & $\mathrm{NO}$ & YES & \multirow{2}{*}{$\chi^{2}$} & $\mathrm{NO}$ & YES & \multirow{2}{*}{$\chi^{2}$} \\
\hline & $\%$ & $\%$ & & $\%$ & $\%$ & \\
\hline $\begin{array}{l}\text { Two-parent } \\
\text { (complete) }\end{array}$ & 87.03 & 70.08 & \multirow{3}{*}{$64.54 * * *$} & 87.70 & 77.45 & \multirow{3}{*}{$71.60 * * *$} \\
\hline Single-parent & 12.49 & 28.03 & & 11.91 & 21.07 & \\
\hline Reconstituted & 0.48 & 1.89 & & 0.39 & 1.48 & \\
\hline
\end{tabular}

$* \mathrm{p}<0.05 ; * * \mathrm{p}<0.01 ; * * * \mathrm{p}<0.001$

TABLE 11. Alcohol abuse by a family member in adolescents reporting suicidal ideation and plans.

\begin{tabular}{|c|c|c|c|c|c|c|c|c|}
\hline \multirow{3}{*}{ Variables } & \multicolumn{4}{|c|}{ Suicidal ideation } & \multicolumn{4}{|c|}{ Suicide plans } \\
\hline & NO & YES & \multirow{2}{*}{$\chi^{2}$} & \multirow{2}{*}{$\mathrm{p}$} & NO & YES & \multirow{2}{*}{$\chi^{2}$} & \multirow{2}{*}{$\mathrm{p}$} \\
\hline & $\%$ & $\%$ & & & $\%$ & $\%$ & & \\
\hline $\begin{array}{l}\text { Alcohol } \\
\text { abuse by } \\
\text { a family } \\
\text { member }\end{array}$ & 14.73 & 29.38 & 160.30 & 0.001 & 16.92 & 31.86 & 107.61 & 0.001 \\
\hline
\end{tabular}

TABLE 12. Alcohol abuse by a family member in adolescents performing suicide attempts and self-injury.

\begin{tabular}{|c|c|c|c|c|c|c|c|c|}
\hline \multirow{3}{*}{ Variables } & \multicolumn{4}{|c|}{ Suicide attempts } & \multicolumn{4}{|c|}{ Self-injury } \\
\hline & $\mathrm{NO}$ & YES & \multirow{2}{*}{$\chi^{2}$} & \multirow{2}{*}{$\mathrm{p}$} & $\mathrm{NO}$ & YES & \multirow{2}{*}{$\chi^{2}$} & \multirow{2}{*}{$\mathrm{p}$} \\
\hline & $\%$ & $\%$ & & & $\%$ & $\%$ & & \\
\hline $\begin{array}{l}\text { Alcohol } \\
\text { abuse by } \\
\text { a family } \\
\text { member }\end{array}$ & 17.73 & 32.52 & 44.91 & 0.001 & 16.11 & 33.29 & 138.18 & 0.001 \\
\hline
\end{tabular}

and plans and performing suicide attempts and self-injury experienced psychological, physical and sexual violence in the family, they inform about alcohol abuse by a family member and are raised in a single parent family or reconstituted family. Zoroglu et al. [12] found that significantly more adolescents performing suicide attempts experienced emotional violence $(50.0 \%$ vs $11.8 \%)$, physical violence $(42.0 \%$ vs $10.3 \%)$ and sexual violence (20.3\% vs $6.1 \%)$ as compared to the individuals not prone to suicide attempts. According to Wichstrøm [17], being brought up in a single-parent family is another factor affecting suicide attempts in adolescents. Park et al. [2] list divorces and parents' alcohol addiction among the factors pushing boys to suicidal thoughts.

The study of the prevalence of the risk factors of suicide attempts and self-injury by adolescents conforms fully to the National Programme of Mental Health Protection. The results of this research can be used while designing preventive programmes focused on preventing suicide attempts by adolescents.

\section{CONCLUSIONS}

1. The researchers looked at a group of 6883 adolescents living in Lublin Province, aged between 13 and 19. These individuals reported suicide ideation at a rate of $47.65 \%$, suicide plans at a rate of $32.35 \%$, suicide attempts were made by $10 \%$ of adolescents and self-injury by $24.91 \%$ of the respondents aged 13 to 19 years. 
2. The adolescents aged 17 are most prone to suicide ideation, plans and attempts as well as self-injuries.

3. Inflicting self-injury is much more common in adolescents living in the urban areas, as compared to those living in rural areas.

4. The individuals reporting suicidal tendencies, e.g. suicide attempts and self-injury, are much more likely to abuse alcohol and other psychoactive substances.

5. The adolescents reporting suicide attempts and self-injury, are more likely to have experienced psychological, physical and sexual violence in their families, have been raised by single parents or in families, where one of the parents abused alcohol.

\section{REFERENCES}

1. Hołyst B. Motywacje samobójstw nieletnich. Ministerstwo Sprawiedliwości. Probacja. 2012;3:19-42.

2. Napieralska E. Epidemiologia zgonów dzieci i młodzieży z powodu samobójstw w Polsce w latach 1999-2006. Probl Hig Epidemiol. 2010;91(1):92-8.

3. Gmitrowicz A. Społeczne i psychiatryczne uwarunkowania prób samobójczych u młodzieży. Postępy Psychiatr Neurol. 1999;8:457-64.

4. Komenda Główna Policji. [http://statystyka.policja.pl]

5. Rosa K, Gmitrowicz A. Regionalny Program Zapobiegania Samobójstwom Młodzieży Część I. Charakterystyka populacji regionu łódzkiego. Suicydologia. 2007;3(1):18-22.

6. Rosa K., Merecz D. Międzynarodowy Program Badań nad Zachowaniami Samobójczymi - SUPRE-MISS. Suicydologia. 2005;1:92-7.
7. Gmitrowicz A, Dubla W. Zachowania samobójcze w reprezentatywnej grupie młodzieży z terenu Łodzi. Psychiatr Psychol Klin Dzieci Młodz. 2001;3:236-43.

8. Główny Urząd Statystyczny. Zdrowie dzieci i młodzieży w Polsce w 2009 r. Kraków; 2011.

9. Żechowski C, Namysłowska I. Kulturowe i psychologiczne koncepcje samouszkodzeń. Psych Pol. 2008;42(5):647-57.

10. Klonsky ED. Non-suicidal self-injury in United States adults: prevalence, sociodemographics, topography and functions. Psychol Med. 2011;41(9):1981-6.

11. Pawłowska B, Potembska E, Zygo M, et al. Rozpowszechnienie samouszkodzeń dokonywanych przez młodzież w wieku od 16 do 19 roku życia. Psych Pol. 2016;50(1) (in press).

12. Zoroglu SS, Tuzun U, Sar V, et al. Suicide attempt and self-mutilation among Turkish high school students in relation with abuse, neglect and dissociation. Psychiatry Clin. Neurosci. 2003;57(1):119-26.

13. Lewinsohn PM, Rohde P, Seeley JR, Baldwin CL. Gender differences in suicide attempts from adolescence to young adulthood. J Am Acad Child Adolesc Psychiatry. 2001;40(4):427-34.

14. Borges G, Walters EE, Kessler RC. Associations of substance use, abuse, and dependence with subsequent suicidal behavior. Am J Epidemiol. 2000;151(8):781-9.

15. Nock MK, Green JG, Hwang I, et al. Prevalence, correlates, and treatment of lifetime suicidal behavior among adolescents: results from the National Comorbidity Survey Replication Adolescent Supplement. JAMA Psychiatry. 2013;70(3):300-10.

16. Zakharov S, Navratil T, Pelclova D. Suicide attempts by deliberate selfpoisoning in children and adolescents. Psychiatry Res. 2013;210(1):3027.

17. Wichstrøm L. Predictors of adolescent suicide attempts: a nationally representative longitudinal study of Norwegian adolescent. J Am Acad Child Adolesc Psychiatry. 2000;39(5):603-10.

18. Kelly TM, Lynch KG, Donovan JE, Clark DB. Alcohol use disorders and risk factor interactions for adolescent suicidal ideation and attempts. Suicide Life Threat Behav. 2001;31(2):181-93.

19. Wu P, Hoven CW, Liu X, et al. Substance use, suicidal ideation and attempts in children and adolescents. Suicide Life Threat Behav. 2004;34(4):408-20.

\section{Corresponding author}

Beata Pawłowska

1 Głuska Str., 20-439 Lublin,

Tel. 81 744-09-67

E-mail: pawlowskabeata@tlen.pl 